\title{
CITY CEMETERIES AS CULTURAL ATTRACTIONS: TOWARDS AN UNDERSTANDING OF FOREIGN VISITORS’'ATTITUDE AT THE NATIONAL GRAVEYARD IN BUDAPEST
}

\author{
Brigitta PÉCSEK ${ }^{\mathrm{a}}$ \\ ${ }^{a}$ Szent István University, Gödöllö, Hungary, György Enyedi, Doctoral School of Regional Sciences, \\ Gödöllö, Páter Károly utca 1, 2100 Hungary Tisza Lajos. Krt. 47, phone: +36 30417 6348, e-mail: \\ brigitta.pecsek@gmail.com \\ Cite this article: Pécsek, B. (2015). City Cemeteries as Cultural Attractions: Towards an \\ Understanding of Foreign Visitors' Attitude at the National Graveyard in Budapest. Deturope, 7, 1: \\ 44-61
}

\begin{abstract}
The paper aims to reposition urban cemeteries within the tourism supply and to showcase their values as cultural tourism products that can enrich visitors' experiences. Although urban cemeteries as ritual meeting points of life and death have become an integral part of city tourism, contemporary tourism literature mostly embeds them in dark tourism or thanatourism, neglecting the experience-rich potentials of cemeteries as cultural products. This paper rectifies this by arguing that cemetery tourism makes a fascinating cultural display for tourists, offering both nature-based and cultural activities, therefore, it can be rightfully placed in heritage and cultural tourism. The paper investigates foreign visitors' attitude at the National Graveyard in Budapest. During the empirical research 52 questionnaires were correctly filled in, followed by the same number of mini-interviews. The research findings confirmed the initial hypotheses: 1. Visitors regarded cemeteries as complex attractions representing both natural and cultural values, which added to the positive experiences of a Budapest city break. 2. There was no reference to the so called "dark aspects" of cemeteries in the answers. 3 . Although the satisfaction rate was high, the lack of visitors is a clear indication that the cemetery in Budapest has been so far undervalued as an urban attraction. On the negative side, respondents criticized the lack of information sources available prior to visit, the inefficient marketing and the undesirable neighbourhood. The paper ultimately aims to provide stakeholders solid, preliminary data that might serve as a launching pad for further larger-scale research.
\end{abstract}

Key words: cemeteries, urban tourism, dark tourism, Budapest, cultural tourism, Kerepesi cemetery,

„It is a good place to spend an afternoon or maybe eternity.” Anonymous tourist INTRODUCTION

Cemeteries as ritual meeting places of the living and the dead have become an integral part of urban tourism supply. Several urban cemeteries such as Pere Lachaise are major draw 
cards for city breakers, enjoying cultural pursuits in a metropolitan environment. However, the bulk of academic literature focuses on cemeteries' anthropological and architectural aspects (Francis, 2003; Gecséné Tarr, 2012; Johnson, 2008; Rugg, 2000), while within the theoretical frame of tourism cemeteries are mostly related to dark tourism or thanatourism (Lennon \& Foley, 1996; Seaton, 1996, 1999, 2002; Seaton \& Lennon, 2004; Sharpley \& Stone, 2009; Stone, 2006), neglecting the cultural aspects of urban cemeteries.

In the first part, contemporary theories with regard to dark tourism are presented to outline the theoretical framework within which cemeteries are usually discussed. Then, the paper moves onto showcasing cemeteries as experience-rich, complex tourism attractions with excellent potentials to complement a city break of cultural nature.

The investigative part of the study comprises the empirical research, in which the main focus was placed on the foreign visitors' attitude at the National Graveyard in Fiumei Street (also called Kerepesi Cemetery), in Budapest. At the time of the research there was no solid secondary data to rely on, therefore, no yardsticks were available against which my findings could be evaluated. This problem was coupled with the low visitation rate of the cemetery, which I experienced during my initial visits.

To counterbalance the small sample size, mixed research methods seemed more appropriate to harness quality data and gain the best insight possible into the attitude of visitors in relation to their cemetery visit. Therefore, after filling in the questionnaires, I conducted mini-interviews with the same 52 participants. The actual survey took place on two Mondays, Wednesdays, Saturdays and Sundays, in March 2013. The sample size was non-representative and the research was of exploratory character.

The findings proved that visitors unequivocally regarded the graveyard as the integral part of the city's cultural landscape. They embraced the sharp contrast between the hectic city centre and the serenity of the cemetery without actually leaving the metropolitan area behind. The primary reasons for their visit included the opportunity to escape from the hustle and the bustle of the city as well as to appreciate the natural surroundings. In addition, they also engaged in several cultural activities such as taking photographs, visiting certain tombs or expanding their knowledge. The respondents did not make any reference to the "dark nature" of cemeteries, so the conclusions can be rightfully drawn that city cemeteries created an additional value for city breakers, which were of cultural nature rather than associated with death or suffering. The paper ultimately aims to reposition cemeteries within the tourism framework, to lay the initial empirical foundation 
Pécsek, B.

and to act as a catalyst for more comprehensive and larger-scale research into the potential touristic use of the National Graveyard, Budapest.

\section{Position of Cemeteries in Tourism}

According to Oxford dictionaries ( $\underline{w w w . o x f o r d d i c t i o n a r i e s . c o m, ~ 2013) ~ a ~ c e m e t e r y ~ i s ~, a ~}$ place for burying the dead; a graveyard." In tourism literature cemetery is linked to dark tourism and the phenomenon was first labelled by Lennon \& Foley (1996). Their definition of dark tourism says (1996, p.198) "the phenomenon which encompasses the presentation and consumption (by visitors) of real and commoditized death and disaster sites". A decade later Tarlow (2005, p.48) defines the concept as "visitation to places where tragedies or historically noteworthy death has occurred and that continue to impact our lives". Dark tourism for Sharpley and Stone $(2009$, p. 4) mean "for as long as people have been able to travel, they have been drawn - purposefully or otherwise - towards sites, attractions or events that are linked in one way or another with death, suffering, violence or disaster".

Another well-known scholar, Seaton (1996, p. 234) favours the term thanatourism and describes the thanatourist "a tourist motivated by the desire for actual or symbolic encounters with death." Seaton distinguished the following types of thanatourism:

1. Travel to watch death such as public hangings or executions

2. Travel to sites after death occurred such as Auschwitz

3. Travel to internment sites and memorials such as graves and crypts

4. Travel to reenactments such as Civil War reenactments

5. Travel to synthetic sites at which evidence of the dead has been collected such as museums

According to Stone (2006, p.146) „Dark tourism is visiting or travelling to those sites that are associated with tragedy and death." He points out that certain sites may be darker than others due to their characteristics, perceptions and product traits. Using his model each dark tourism product can be described and analyzed. 
Figure 1 Dark-light spectrum scale

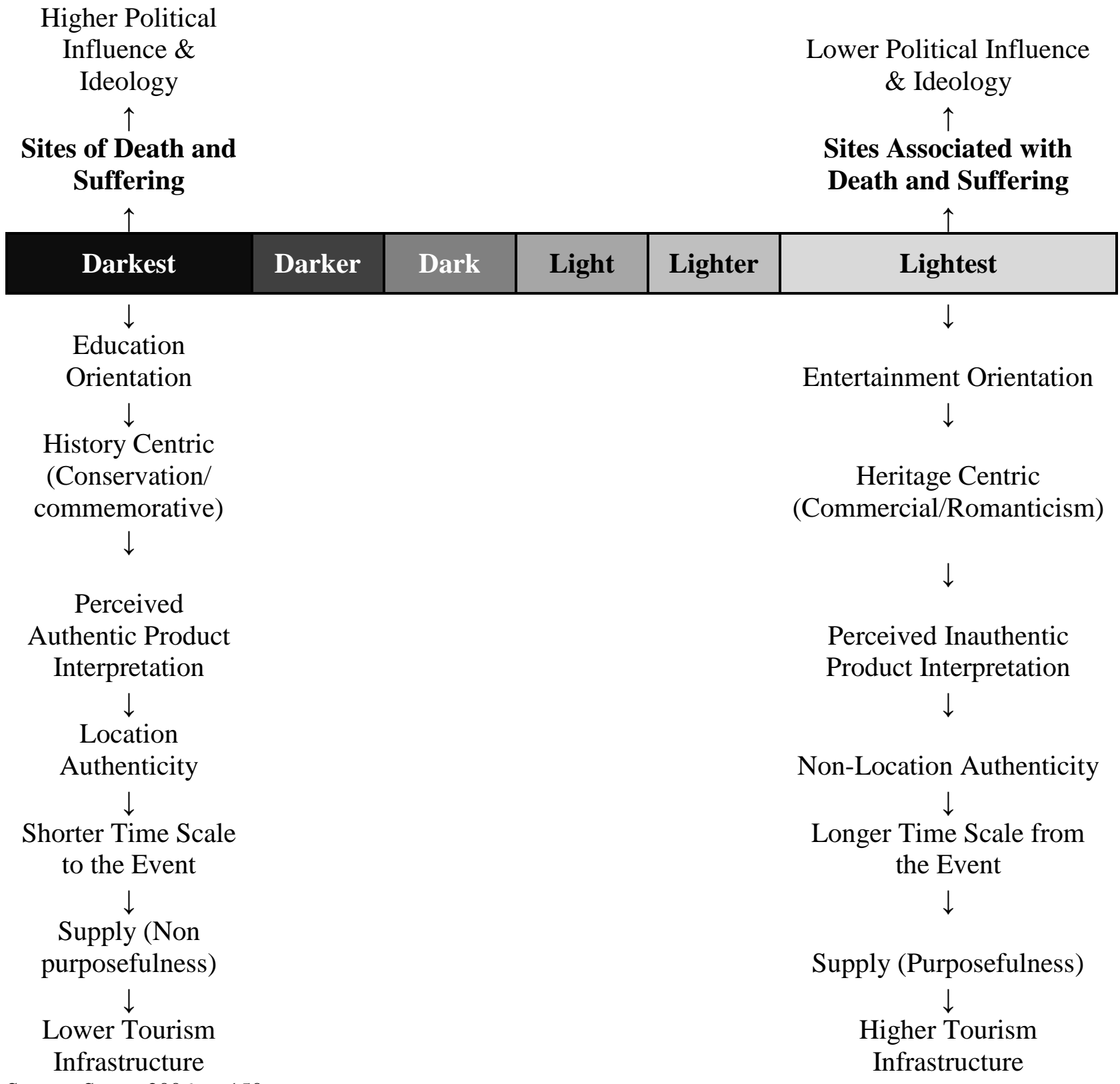

Based on Stone's spectrum scale, cemeteries lie on the darker end of the spectrum. They are sights of death, giving educational, history-centric information and interpretations of the past. Furthermore, they are unstaged, authentic sites with no purposeful supply, providing low-level infrastructure. However, there is much more to cemeteries than darkness as many cemeteries around the world prove.

\section{The Case for Cemetery Tourism}

Cemeteries are abundantly featured on the UNESCO World Heritage List (www.unesco.org). Altogether 55 have been honoured to date (2014), including city 
cemeteries in Cracow, Prague, Venice or Salzburg. Europe is particularly rich in heritage urban cemeteries; most metropolitan areas have at least one cemetery of note. The Association of Significant Cemeteries in Europe (ASCE, www.asce.org) recognized the need for their protection and their joint promotion. The organization has 179 member cemeteries in 22 countries in 2014 that share experience and best practices and cooperate to protect, restore and ensure ongoing care and maintenance. The organization emphasizes that cemeteries are both tangible and intangible heritage. They are witnesses of local history as well as reveal the given community's cultural and religious identity. The association has put together a thematic route that is one of the certified Europe Cultural Routes (ASCE, www.asce.org, 2014).

There are plenty of idiosyncratic graveyards scattered around the world, giving fascinating insights into past and modern societies' perceptions to life and death. Cross Bones for instance is a cemetery in London, where 15,000 paupers and prostitutes were buried in the late medieval times (www.crossbones.org.uk, 2014). In the still functioning Merry Cemetery in Sapenta, Romania dead people are honoured with carved crosses containing pictures and verses related to the deceased person's life. The Chinese Bo tribe wiped out in the 16th century used to bury their dead in coffins hanging off the steep cliffs. Tana Toraja, Indonesia boasts some of the finest cliff cemeteries and eccentric funerary rituals including pig and buffalo slaughters, accompanied with six-week constant singing and dancing (Cockman, 2013). In Nokhur, Turkmenistan graves are marked by a wooden post adorned with the horns of a mountain goat (www.atlasobscura.com, 2014). In the Cemetery of the Nameless, Vienna the 104 bodies were unidentified as victims of drowning before 1940, which the river's current brought ashore (www.wien.info/en). To a certain extent, all these burial places have some dark aspects; however, for seasoned travellers these cultural landscapes offer a whole other spectrum of cultural interpretations, legends, stories and art history.

Cemetery tourism is fuelled by some intriguing contemporary phenomena. „Goods and services are no longer enough". - say Pine \& Gilmore (1999, 2012, p.1), and the shift from the service economy towards to experience economy creates ideal conditions for niche products. Cemeteries as complex attractions certainly fit the bill, offering a variety of experiences for visitors. In our advanced world people yearn for the experience of the authentic, and in urban tourism context cemeteries can be the crown jewel of city breaks. With the help of the Pine \& Gilmore model, it can be easily proven that cemeteries guarantee all four experiences necessary for a fully-satisfying visit. 
Figure 2 Pine - Gilmore Experience Realms

\begin{tabular}{|c|c|c|}
\hline & Absorb & \\
\hline $\begin{array}{c}\text { Passive: Entertainment } \\
\text { Aesthetic }\end{array}$ & & $\begin{array}{c}\text { Active: Educational } \\
\text { Escapist }\end{array}$ \\
\hline & Immerse & \\
\hline
\end{tabular}

Source: Pine \& Gilmore, 2012, p. 46

The model includes two passive experiences: entertainment and aesthetic and two active experiences: educational and escapist. The cemetery's natural landscape with the green spaces, the paths crisscrossing, the benches scattered around, coupled with the architecture gives the aesthetic pleasure to the eye. While cemetery programs such as concerts fulfill the entertainment requirement. Searching for the resting places of famous people and learning about their lives and achievements widen visitors' horizons in terms of knowledge and information. While taking part in a local burying ritual is both escapist and educational. It allows tourists to place themselves into a spiritual sphere and co-produce the unrepeatable, one-off common narrative (Niedermüller, 2000). Fromm (1973) suggests that group experiences like this are the deepest and most unforgettable experiences humankind can live through. "The experiences we have affect who we are, what we can accomplish, and where we are going" - say Pine \& Gilmore $(1999,2012)$ in their groundbreaking book. These days more and more people yearn to find their inner self and transform themselves into a more aware and spiritual person, and experiences can certainly help them go through this journey. Michalkó (2012, p. 34) also stresses the importance of experiences in his alternative tourism definition ,tourism is a change of environment during which experiences are collected and services are used."

However, different cemeteries provide a different set of experiences, greatly depending on their style, especially the layout and the proportion of built structures versus green spaces. Some are more like outdoor sculpture museums while others are rather lawn parks, the rest is somewhere in between. Gecséné Tarr (2012) identified three main European cemetery cultures. Neo-Latin countries like France, Italy, Spain and Portugal focus on the prominent tombs and crypts, while greenery plays a secondary role. In contrast, in Western countries like Germany, the Netherlands and England the natural landscape is a key feature. As a result, lawns are more important than flowers and plants. The Northern countries including Sweden, Norway and Denmark have so called „lawn cemeteries”, without proper paths and there are scarcely planted trees, bushes and flowers. In Central Europe the eclectic blend of Western and Latin style reigns supreme. 
Regardless of their design, cemeteries have complex attraction power. "Attraction incites tourists to go to a place" (Michalkó 2012, p. 93). Puczkó \& Rátz (2003) argue that modern tourists have become more seasoned travellers with more sophisticated needs and expectations, therefore, niche products might be more appealing to them than to their parents. Seaton (2002), Meyer \& Peters (2001) also acknowledge „Dark Resting Places” as urban regeneration tools. Furthermore, cemetery tourism will also profit from the ageing of modern societies where an ever growing number of seniors continue to travel, and mature age tourists are keen to enjoy cultural offerings with a natural slant such as cemeteries.

Accessibility in a physical and abstract sense is also important in urban tourism because city breakers are usually time-poor. Most urban cemeteries are centrally-located, and visitation does not require complicated preparation and planning. It is easy to make sense of the place, because death is a common experience for mankind, therefore, they are universal places where people move around with ease. At the same time, in contrast to global, transnational urban spaces surrounding them, city cemeteries are imprints of the given national culture. Their "glocal" (global + local) nature, this idiosyncratic mix of the familiar and the unknown makes cemeteries compelling "must see" places.

\section{The National Graveyard, Budapest}

The National Graveyard known also as Kerepesi Cemetery is the most centrally located cemetery in Budapest, lying about 500m southeast of Keleti Railway Station, the main entrance to Budapest. It was established in 1847 and presently is one of the biggest National Pantheons and outdoor statue parks in Europe comprising an area of about 56 hectares. Currently, it boasts 3000 gravestones and mausoleums and it is the final home to the finest statesmen and national heroes such as Lajos Kossuth, Ferenc Deák and Lajos Batthyány. The cemetery is shared by victims of the 1956 Uprising alongside with the emblematic figure of socialism, János Kádár and the first prime minister after the 1989 regime change, József Antal. Some of the most prominent scientists also rest there, namely Leó Szilárd, Ignácz Semmelweis or George de Hevesy among others. As part of the "Long Night of the Museums" Celebration the cemetery holds an event called the "Day of the Bells" every June. Besides, they also put together thematic tours for schools and tourists. The cemetery houses a funerary museum that visitors can see for free of charge (www.nemzetisirkert.hu, 2014). 


\section{MATERIALS AND METHODS}

In terms of methodology, I had to face some sampling dilemma at the outset. Since cemeteries primarily are resting and meeting places where the living and the dead can be symbolically reunited, asking for an entry fee would be morally unjustified. As a result of the free entry, it is impossible to estimate visitation size, let alone distinguish between local regulars and tourists. So, any data or quantitative analysis is hard to come by. Consequently, non-representative, random sampling was the only feasible alternative. In practical terms it meant that I tried to identify tourists by observing their props such as maps and cameras as well as their behaviour, then approached and asked them to fill in the questionnaire, then answer my interview questions.

The sampling problem raises the question of why bothering with such a small sample at all. It might only be answered with another question. How can you make any assumptions regarding the neglect of the cemetery as a tourism attraction, if you ignore tourists who have paid their visit? The core of this survey revolves around questions dealing with free association and satisfaction, and those components make the research worthwhile irrespectively of the actual sample size. In this case the demographical details and travel particulars served merely as a statistical backdrop and the main focus was on the qualitative nature of the research, namely on the interviews regarding attitude and satisfaction.

Eventually, the actual survey took place in two Mondays, Wednesdays, Saturdays and Sundays, in March 2013 at the entry gate of the Kerepesi cemetery. The research consisted of two components. First, 52 foreign individual visitors filled in a questionnaire, and then the survey was supported by semi-structured mini-interviews with the same participants. Ultimately, 30 men and 22 women were willing to take part in the mixed-method survey. 50 were first-time visitors in the cemetery. The written and verbal questions centred around the following topics:

- Demography of visitors

- Travel particulars: type of accommodation used, length of stay,

- Information sources used prior to visit

- Activities performed during the visit

- Associations related to the cemetery visit

- Positive and negative experiences during the visit

- Satisfaction with the visit 
- Suggestions for improvements

During the research the main reason for the tiny size of visitors also became clear. The lack of awareness among tourists was a recurring theme during the mini-interviews. In fact, even those foreign visitors who made it to the cemetery complained about the invisibility of the cemetery as an urban attraction.

\section{RESULTS AND DISCUSSION}

Table 1 Demography and travel details of foreign visitors

\begin{tabular}{|c|c|c|c|}
\hline \multicolumn{2}{|c|}{ Features } & $\mathbf{N}$ & $\%$ \\
\hline \multirow{2}{*}{ Gender } & Male & 30 & $57.69 \%$ \\
\hline & Female & 22 & $42.31 \%$ \\
\hline \multirow{5}{*}{ Age } & $18-24$ & 8 & $15.38 \%$ \\
\hline & $25-34$ & 21 & $40.38 \%$ \\
\hline & $35-44$ & 7 & $13.46 \%$ \\
\hline & $45-54$ & 7 & $13.46 \%$ \\
\hline & Over 55 & 9 & $17.31 \%$ \\
\hline \multirow{3}{*}{$\begin{array}{l}\text { Length of stay } \\
\text { (in days) }\end{array}$} & $1-2$ & 19 & $36.54 \%$ \\
\hline & $3-5$ & 31 & $56.36 \%$ \\
\hline & 6 or more & 2 & $5.56 \%$ \\
\hline \multirow{5}{*}{ Accommodation } & $4 *$ - hotel & 22 & $42.31 \%$ \\
\hline & $3 *$-hotel & 12 & $23.08 \%$ \\
\hline & Private room & 2 & $3.85 \%$ \\
\hline & Hostel & 14 & $26.92 \%$ \\
\hline & Family and Friends & 2 & $3.85 \%$ \\
\hline \multirow{9}{*}{ Country } & Australia & 2 & $3.85 \%$ \\
\hline & Belgium & 4 & $7.69 \%$ \\
\hline & Finland & 2 & $3.85 \%$ \\
\hline & The Netherlands & 2 & $3.85 \%$ \\
\hline & The United Kingdom & 8 & $15.38 \%$ \\
\hline & Germany & 6 & $11.54 \%$ \\
\hline & Italy & 12 & $23.08 \%$ \\
\hline & Switzerland & 2 & $3.85 \%$ \\
\hline & USA/Canada & 14 & $26.92 \%$ \\
\hline Total & & 52 & $100 \%$ \\
\hline
\end{tabular}

Source: own collection, 2013 
Figure 3 Information source used prior to visit

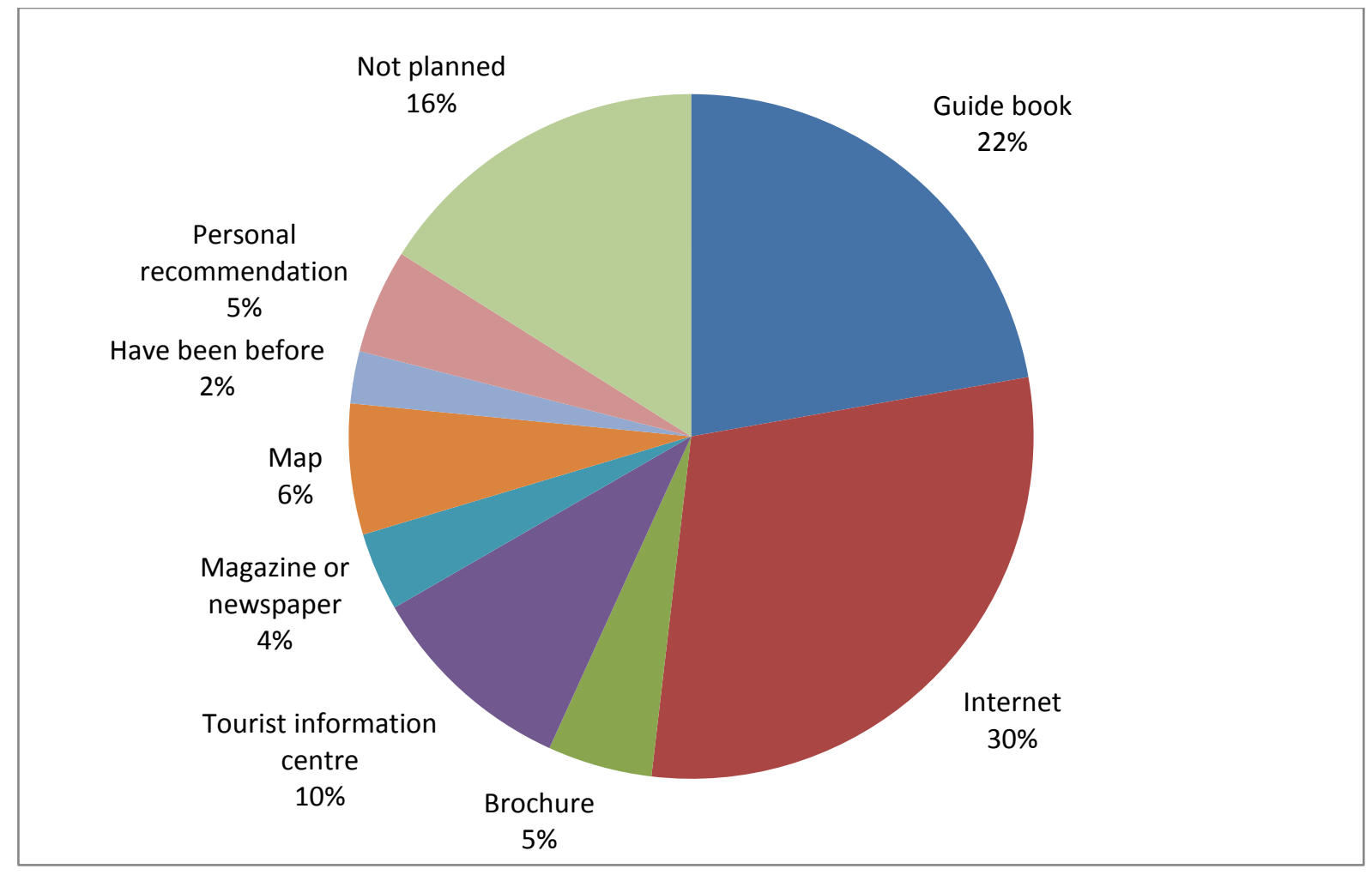

Source: own collection, 2013

Respondents were asked to identify the kind of information source they had used prior to their visit. The data captured suggest that the Internet was the most popular source of information prior to visit with $30 \%$. However, guidebooks still played an important role, $22 \%$ of visitors used them before their trip. Other sources remained negligible. It is interesting to note that although information centres (Tourinform offices) in Budapest are centrally-located, they were not featured prominently. Only one tenth of visitors entered an office to get information. The non-planned visitation rate is also high, $16 \%$ of people went to the cemetery spontaneously without any preparations. Those spontaneous visitors fitted the cemetery into their last day itinerary, and the accessibility of the sight played an important role in their decision. There were a low proportion of repeat visitors (2 people). For those who left Budapest by train, the cemetery was the last attraction visited. No one used travel brochures, the media or the map as preliminary information sources. Only two people went to the cemetery based on personal recommendation. So, the world of mouth advertising is negligible in that case. 
Table 2 Activities undertaken during visit

\begin{tabular}{|l|l|l|}
\hline Activities & N & $\%$ \\
\hline Walking & 44 & $84.62 \%$ \\
\hline Visiting famous tombs & 24 & $46.15 \%$ \\
\hline Photography & 20 & $38.46 \%$ \\
\hline Visit to the museum & 38 & $73.08 \%$ \\
\hline Study and research & 2 & $3.85 \%$ \\
\hline No. of visitors / No. of activities & $52 / 128$ & \\
\hline
\end{tabular}

Source: own collection, 2013

As for the various activities undertaken, respondents were allowed to choose all the activities they performed without any forced order of preference. What emerges from this examination is that walking was the most frequent activity mentioned by $84 \%$ of people. Two thirds of them visited the funerary museum there, and almost half went to look for specific tombs. $38.4 \%$ took photos, but only a couple went there for study and research purposes. To sum up, 52 visitors undertook 128 activities, so they took out a lot of mileage of their visit, doing at least two activities on average. During their visit physical exercise such as walking and cultural pursuits were done simultaneously.

Table 3 Associations regarding the National Graveyard

\begin{tabular}{|c|c|}
\hline Mention & $\%$ \\
\hline General adjectives & $41.67 \%$ \\
\hline Inspirational & $20.00 \%$ \\
\hline Huge & $5.00 \%$ \\
\hline Sad & $5.00 \%$ \\
\hline Worth a day & $5.00 \%$ \\
\hline Authentic & $5.00 \%$ \\
\hline Superb & $5.00 \%$ \\
\hline Impressive & $20.00 \%$ \\
\hline Unknown wonder & $5.00 \%$ \\
\hline Nice walk after spa & $10.00 \%$ \\
\hline Better than Pere Lachaise & $20.00 \%$ \\
\hline History & $29.17 \%$ \\
\hline Eternal memory & $42.86 \%$ \\
\hline Revolution of 1956 & $57.14 \%$ \\
\hline Culture & $25.00 \%$ \\
\hline
\end{tabular}


Table 3 (Continued)

\begin{tabular}{|c|c|}
\hline Mention & $\%$ \\
\hline Jancsó's film & $8.33 \%$ \\
\hline Art history & $8.33 \%$ \\
\hline Sculpture park & $8.33 \%$ \\
\hline Lujza Blaha & $8.33 \%$ \\
\hline Outdoor museum & $33.33 \%$ \\
\hline Nature & $4.17 \%$ \\
\hline Birds and squirrels & $100.00 \%$ \\
\hline Total & $100.00 \%$ \\
\hline
\end{tabular}

Source: own collection, 2013

Table 3 contains all the associations visitors came up with in connection with their visit. Mentions were grouped into four categories: general adjectives, history, culture and nature. General adjectives were the most frequently said $(41,67 \%)$ and none of the words could be related to death and sufferings. Only one adjective had a somewhat negative connotation in our culture: „sad”. „Inspirational”, „impressive” and "better than Pere Lachaise” were the most popular reactions in that category. Comparing Kerepesi Cemetery with the most recognizable cemetery in Europe is very flattering and shows how undervalued the Hungarian cemetery really is and to such an extent its potential is underutilized. $10 \%$ of respondents linked the cemetery visit to a spa experience. It is intriguing in a sense that both products (cemetery and spa) are on the slower end of activities and yet attractive for city breakers. It suggests that a variety of tourism products and activities have their own places in urban tourism offerings, and city breaks have much more to offer than museums, shopping and clubbing.

Associations linked to historical events made up $30 \%$ of all mentions. $57 \%$ of the answers recalled the 1956 revolution and the only other mention was ,eternal memory”. It was no surprise because this historic event is the closest to our times and the Western world was also affected in terms of political refugees fleeing to their countries. It was already a mediatized world back then, therefore, the outside world had access to information, and the survivors' stories may keep the collective memory alive.

Associations linked to culture made up the fourth of all mentions and „outdoor museum" was the most frequently said. Two concrete names appeared among the verbal reactions: Blaha Lujza, the most beloved actress by Hungarians and Jancsó Miklós, the most widely recognized film maker. It is striking that the film maker was still alive at that 
time (died in February, 2014), however, love and death was a prominent theme in his films. Although walking was the primary activity for visitors, associations linked to nature were scarcely mentioned, in both cases visitors picked upon the fauna of the cemetery and mentioned birds and squirrels. Interestingly, the landscape or the green spaces were completely missing from the reactions, which might mean that they serve only as a picturesque backdrop of the more exciting pursuits.

Table 4 Satisfaction with visit

\begin{tabular}{|l|l|}
\hline Scale of satisfaction & $\%$ \\
\hline Very satisfied & $73.08 \%$ \\
\hline Satisfied & $25.00 \%$ \\
\hline Neutral & $1.92 \%$ \\
\hline Dissatisfied & $0.00 \%$ \\
\hline Very dissatisfied & $0.00 \%$ \\
\hline Total & $100.00 \%$ \\
\hline
\end{tabular}

Source: own collection, 2013

A closer look at the scale of satisfaction reveals that the vast majority of participants, $73.08 \%$ were very satisfied with their visit to the cemetery. In fact, it exceeded their expectations - as most stated at the interview. Only one respondent left with a "neutral" experience. No negative reaction regarding satisfaction came from the respondents. When they were asked if they would recommend the cemetery to their families and friends, they answered in the affirmative.

Figure 4 Features contributed the most to the enjoyment of tourists' visit (on a scale of 1-5)

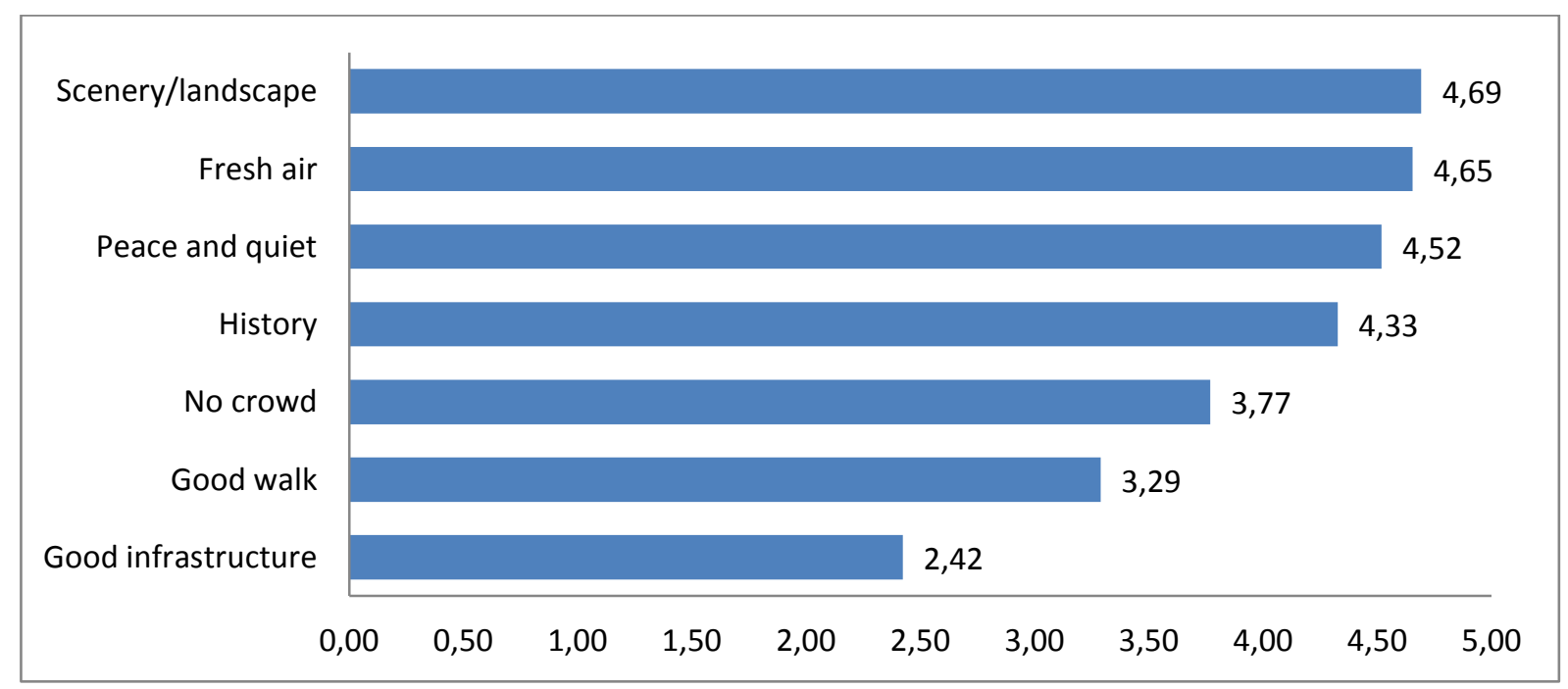

Source: own collection, 2013 
Next, respondents had to evaluate seven features on a scale of 1-5 responsible for the enjoyment of their visit, where 5 indicated the most important contributor. They were allowed to give the same value to any features and did not have to make any forced order of preference. Since the paper tries to make a point about cemeteries as complex attractions, offering a variety of experiences, a forced ranking would have defeated the purpose of the research. The highest value was attached to „scenery and landscape” and „fresh air", but "peace and quiet" and "history" also received an above 4 average. The "lack of crowd" and "good walk" were appreciated, however, visitors did not find good infrastructure important, ordering only a 2.42 value to that feature.

There was also a question posed about the features that might have spoilt respondents' visit. Participants had to choose values from a set of questions that might have caused any inconvenience for them. Regarding the infrastructure or the lack of it, none of them mentioned the lack of toilets, the shortages of benches or the conditions of paths as a problem. Visitors did not require organized walks, more interpretations or better maps. They refuted the idea of commoditization of the cemetery, and they did not want to see any commercial establishments such as eateries or refreshment vans in the area. On the opposite, they favoured the unstaged, uncustomized experience.

The last question was posed about suggestions for possible improvements, and visitors had three recurrent themes. They heavily criticized the cemetery surroundings, including Keleti railway station with its illegal sellers and beggars, which is a great shame because "the being in-between places" are part of the overall experience. This is the time when anticipation grows gradually. The second problematic issue was the shortage of information sources prior to their visit. The respondents used the Internet and guide books as preliminary sources and they did not find the information available for them satisfactory. Although they passed by Tourinform offices, they did not find their windows inviting enough to enter. They also voiced the problem of inefficient promotions of the cemetery while they were in Budapest. Basically, those tourists who ended up in the cemetery took positive experiences home. The problem arises that due to the scarcity of preliminary information and promotion in Hungary, only a few city tourists venture out to see Kerepesi Cemetery. 
Pécsek, B.

\section{CONCLUSIONS AND RECOMMENDATIONS}

The mixed-method research aimed to analyze and understand foreign visitors' attitude at the National Graveyard in Fiumei Street, Budapest. Although a plethora of research has been done so far on dark tourism or thanatourism, and some of them include cemetery case studies, the cultural attributes of cemeteries through which they can be linked to urban tourism have been neglected. It is unfortunate because cemeteries are usually substantial in size, there is plenty to see and do, as a result, visitations might take hours. So, urban cemeteries are one of those tourism products that can easily extend the average length of a city break.

The survey participants confirmed all of my hypotheses and regarded urban cemeteries as complex tourism products. They visited the cemetery to enjoy nature as well as to find out more about local heritage and culture. So, cemetery visits fitted nicely in other cultural pursuits. The vast majority spent over two hours there, and during their walk, they visited concrete graves and took photographs. They acknowledged and appreciated that the cemetery enriched their knowledge on modern history. One surprising finding was the popularity of the attraction among the younger generation. In academic circles it is widely accepted that urban tourism with a substantial cultural component attracts older generation in greater numbers. In this case it simply has not been confirmed. People aged 18-24 outnumbered other age groups. It is also unexpected that certain nationalities (Austrians, Russians) did not turn up at the cemetery during the research period.

Regarding the feedback all except for one visitor were satisfied with their visit. Respondents mentioned three important shortcomings though: the undesirable surroundings, the shortage of information source prior to their visit and the lack of efficient promotion during their holiday in the city. Without addressing these problems the cemetery continues to mainly welcome accidental tourists who venture to the neighbourhood with no particular expectations and leave pleasantly surprised.

All in all, it is safely assumed that cemetery tourism as part of urban tourism has great potentials, and tourism planners working together with marketing professionals have to tap onto this area less travelled and make urban cemeteries more attractive and accessible in every sense of the word. It is high time to reposition and "whiten the darkened brand"; otherwise, cemeteries will remain a dark niche in the shadow of other more straightforward thana products. Many city cemeteries are simply too mainstream to be included into that 
Pécsek, B.

category, consequently, they can be more efficiently promoted as niche cultural products within urban tourism.

There are several directions further research might take. First of all, the present findings should be tested for larger samples. Another issue worth exploring deeply would be the role of word of mouth advertising in case of niche products. The question is whether the small sample size was the main reason for the fact that only a couple of people arrived thanks to the recommendations of friends and families. Or else, the lack of promotional material to take home to show around prevented tourists from making authentic recommendations at home. It also begs the question what drove young people to visit the cemetery, how different their motivations and needs were from the other age groups'. On a larger scale, the question might arise, where the main differences lie between the young and the "young at hearts" in terms of cultural tourism motivation and consumption. It would be equally important to consider urban cemeteries as slow destinations within a metropolitan environment. As such, they could also play a major role in crowd management since they would give city breakers the chance to slow down their pace and contemplate, while forgetting the hustle and bustle of the city.

\section{SUMMARY}

The paper aims to reposition cemeteries within the tourism supply and to showcase their values as cultural tourism products that can enrich visitors' experiences. Urban cemeteries as ritual meeting points of life and death have become an integral part of city tourism, and several urban cemeteries such as Pere Lachaise in Paris realizes high visitation rate. Contemporary tourism literature mostly embeds cemeteries in dark tourism or thanatourism, neglecting the experience-rich potentials of cemeteries as cultural products. This paper has a different take and does not include cemetery tourism in dark tourism, let alone in the Goth subculture. Since each cemetery is the imprint of the local community and culture and each culture has its own way of dealing with life and death issues, cemetery tourism including the related burying rituals makes a fascinating cultural display for tourists, offering both nature-based and cultural activities. Therefore, it can be rightfully placed in heritage and cultural tourism.

First, the paper presents the contemporary views and concepts of the most renowned thana thinkers, then reflects upon cemetery tourism. To round off this section, urban cemeteries as complex landscapes and attractions are explored.

The main section using a mixed-method research aims to analyze and understand foreign visitors' attitude at the National Graveyard in Fiumei Street, Budapest. The sample size was non-representative and the research was of exploratory character. 52 questionnaires were correctly filled in and the same number of mini-interviews was conducted. The findings confirmed the initial hypotheses: 1. Visitors regarded cemeteries as complex attractions representing both natural and cultural values, which added to the positive experiences of a Budapest city break. 2. Dark aspects of cemeteries did not come up in the answers. 3. Although the satisfaction rate was high, the lack of visitors is a sure sign that the cemetery in Budapest has been so far undervalued as an urban attraction.

On the negative side, respondents criticized the lack of information sources available prior to their visit, the inefficient marketing and the undesirable neighbourhood. Without properly addressing the above problems raised by respondents during the investigation, the cemetery continues to remain an attraction with untapped potentials, and tourists continue to venture out accidentally to the area. The 
Pécsek, B.

ultimate aim is to present high quality, preliminary data to marketers dealing with the tourism of

Budapest, which might trigger further larger scale-research into this field.

\section{LITERATURE}

Association of Significant Cemeteries of Europe. (2014). Retrieved from www.asce.org Atlasobscura. (2014). Retrieved from www.atlasobscure.com

Augé, M. (1992). Non-places: Introduction to supermodernity. London: Verso Books.

Blomfield, A. (22 Feb 2008). Russian Mafia Killings Threaten Putin Legacy. Retrieved from http://www.telegraph.co.uk/news/worldnews/1579733/Russian-mafia-killingsthreaten-Putin-legacy.html

Cemetery of the namless. Retrieved from www.wien.info/en/sightseeing/sights/from-a-tof/cemetery-nameles

Crossbones Graveyard. (2014). Retrieved from www.crossbonesgraveyard.uk

Cockman, L. (2013). Unusual cemeteries. Retrieved from www.dontpaniconline.com/magazine/radar/unusual-cemeteries

Francis, D. (2003). Cemeteries as cultural landscapes. Mortality, 8, 2, 222-227.

Fromm, E. (1973). To have or to be. London: Abacus.

Gecséné Tar, I. (2012). Történelmi temetők Magyarországon. Retrieved from http://phd.lib.uni-corvinus.hu/634/1/Tar_Imola.pdf.

John, C. (2007). Secret bankside: Walks in the outlaw Borough. London: Oberon Books.

Johnson, P. (2008). The modern cemetery: A design for life. Social \& Cultural Geography 9, 7, 779-790.

Lennon, J.J. \& Foley, M. (1996 : 198). Dark tourism. London: Continuum.

Meyer, L. \& Peters, J. (2001). Tourism - A conservation tool for St.Louis cemetery. No 1. Dead Space Studio, University of Pennsylvania, Retrieved from http://cml.upenn.edu/nola/pdfs/Tourism.pdf

Michalkó, G. (2012, p. 14, 93). Turizmológia. Budapest: Akadémiai Kiadó.

Nemzeti Emlékhely és Kegyeleti Bizottság. (2014). Retrieved from www.nemkb.hu

Nemzeti Sírkert. (2014). Retrieved from www.kerepesi.hu

Niedermüller, P. (2000). Városi turizmus. Történelem, művészet, egzotikum. In Z. Fejős \& Zs. Szijártó (Ed), Turizmus és kommunikáció (pp.31-38). Budapest: Néprajzi múzeum.

Oxford Dictionaries, (2013). Oxford: Oxford University Press.

Pine, P. J. \& Gilmore, J. H. (1999, 2012). The Experience economy. Boston: Harward University Press.

Puczkó, L. \& Rátz, T. (2003). Turizmus történelmi városokban. Budapest: Turisztikai Oktató és Kutató KKT.

Rugg, J. (2000). Defining the place of burial: What makes a cemetery a cemetery? 5, 3, 259-275.

Seaton, A.V. (1996). Guided by the Dark: from thanatopsis to thanatourism. Journal of Heritage studies, 2, 234-244.

Seaton, A. V. (1999). War and thanatourism: Waterloo 1815-1914. Annals of Tourism Research, 26, 1, 130-158.

Seaton, A.V. (2002). Thanatourism's final frontiers? Visits to cemeteries, churchyards and funerary sites as sacred and secular pilgrimage. Tourism Recreation Research, 27,2, 73-82.

Seaton, A. V. \& Lennon J.J. (2004). Thanatourism in the early 21 st century. In T. V. Singh (Ed), New Horizons in Tourism: Strange Experiences Stranger Practices. Wallingford: CABI Publishing. 
Pécsek, B.

Sharpley, R. \& Stone, P.R. (2009). The darker side of travel: the theory and practice of dark tourism. Bristol: Channel View Publications

Stone, P. (2006). A dark tourism spectrum: Towards a typology of death and macabre related tourist sites, attractions and exhibitions. Tourism, 54, 2, 145-160.

Szijártó, Zs. (2004). Szinpad és kulissza: A városi nyilvánosság átstrukturálódása. Magyar Tudomány, 10, 1164-1172.

Tarlow, P. (2005). Dark tourism: The appealing "dark" side of tourism and more. In M. Novelli, (Ed.), Niche Tourism. Oxford: Elsevier Butterworth - Heineman.

United Nations Educational, Scientific and Cultural Organization. (2014). Retrieved from www.unesco.org 